\title{
Communication
}

\section{Is the Sustainability Revolution Devouring Its Own Children? Understanding Sustainability as a Travelling Concept and the Role Played by Two German Discourses on Sustainability}

\section{Marcus Knauf}

Knauf Consulting, Dorotheenstraße 7, Bielefeld 33615, Germany; E-Mail: m@knauf-consulting.de; Tel.: +49-521-8973-697; Fax: +49-521-8973-996

External Editor: Eric J. Jokela

Received: 7 October 2014; in revised form: 24 October 2014 / Accepted: 31 October 2014 / Published: 12 November 2014

\begin{abstract}
This paper examines whether the expanded meaning of the term sustainability and its broader use in society, policy and economics will actually bring about the benefits experts anticipate for the forest-based sector. It begins by defining sustainability as a travelling concept, then presents and analyzes two current lines of discourse in Germany on sustainability, both with high relevance for the forest-based sector: strong sustainability and sustainable building. The analysis shows that each discourse has developed and established a diametrically opposed meaning of sustainability. As a result, it could be argued that the two meanings pose a threat to the German forest-based sector by reducing the raw material base and ultimately minimizing market opportunities. This reasoning reveals a paradox: as the term sustainability, originally coined by the forestry sector, becomes mainstream, it could end up limiting the sector's future growth.
\end{abstract}

Keywords: travelling concept; sustainable building; strong sustainability; meaning of sustainability

\section{Introduction}

\subsection{Sustainability as Chance-The Confidence of the German Forest-Based Industry}

Studies on the future of the German wood industry show that experts from the forest-based sector clearly anticipate the importance of sustainability to increase in the building sector $[1,2]$. Most also 
believe the relevance of wood will also increase in the building sector [1,2]. From their perspective, politics is the key driver of this development, not the consumer. The majority of experts assume that politics will establish a statutory framework for ecology and sustainability that benefits wood. Thus, they do not expect a framework that privileges wood use, rather a framework in which wood can prove its strengths as a sustainable raw material. The following article substantiates the expected increase in relevance of sustainable building and standards of sustainability in the building sector, but not the expected benefits for the forest-based sector. The expert's conclusion is plausible, that in a framework privileging sustainability, wood as a sustainable material will succeed. However, it appears that the experts apply another meaning of sustainability than is commonly used or underestimate the revising meaning of the term sustainability.

\subsection{Sustainability on Travel}

Sustainability can be interpreted as a travelling concept. The term travelling concept was introduced by the Dutch cultural scientist Mieke Bal [3] and helps to understand sustainability and its changing meaning. Concepts can be considered "tools of inter-subjectivity" that "facilitate discussion on the basis of a common language. But concepts are not fixed. They travel-Between disciplines, between individual scholars, between historical periods and between geographically dispersed academic communities. Between disciplines, their meaning, reach and operational value differ. These processes of differing need to be assessed before, during and after each "trip". All of these forms of travel render concepts flexible." [4] Examples for travelling concepts are about inclusion [5,6], or class, race and gender [7,8]. Considering sustainability as a travelling concept avoids a normative attribution, like alternative descriptions do, e.g., guiding principle ("Leitbild", $c f$. [9]) and thus, facilitates a scientific access. The following roughly outlines the journey of sustainability.

The starting point for the travel of sustainability is the publication in 1713 by von Carlowitz [10] (forerunner with regard to content in forestry and ethics, $c f$. [11]). For a long time, the concept of sustainability enabled an inter-subjective consensus within the forestry community and traveled between countries ( $c f$. the enhancement of the term in France, Switzerland, Finland and USA which is described by [11]) or (applied) scholarships (e.g., different silvicultural concepts, these of [12-15]). In the 1970 s, the sustainability concept crossed the frontier of the forestry community to eventually become a well-recognized term used by many different communities. The main stops along the journey were the report Our Common Future by the Brundtland Commission [16] and the Rio Declaration on Environment and Development at the Earth Summit in Rio de Janeiro [17]. In particular, the Brundtland Commission established a widely accepted identity-boosting definition of sustainable development. It expanded the term's scope from involving a purely inter-generational approach to one in which inter-generational and intra-generational aspects are equal.

With the largely accepted three-pillar-model (economy, ecology and social aspects) the concept of sustainability appeared to have the power for a broad dialogue permitting inter-subjectivity and overcoming community and country frontiers, e.g., the global founding of local Agenda 21 initiatives (an overview: [18]). A meta-science evolved to manage the inter-subjectivity of sustainability and is aimed at describing the term's core meaning (e.g., [19-22]). As a result, a multitude of new scientific 
journals have appeared focusing on sustainability ("Sustainability Science", "International Journal of Sustainable Development", etc.).

Eventually, the term traveled back home to the forestry community, which adapted and enhanced the three pillars into the term sustainable forest management (SFM) e.g., the Criteria and indicators for the sustainable management of tropical forests [23,24], the Montreal Process [25] or the Pan-European indicators for sustainable forest management [26,27], which define "six criteria, i.e., forest resources and their contribution to global carbon cycles; forest ecosystem health and vitality; productive functions of forests; biological diversity in forest ecosystems; protective functions in forest management; and other socio-economic functions and conditions." [27]. The implementation of SFM led to the establishment of different certification systems (e.g., FSC and PEFC).

The expansion of the meaning has turned the term sustainability into an elastic word with a variety of interpretations and in some circumstances even into a flowery advertising phrase (e.g., [28]). The development of LOHAS (Lifestyle of Health and Sustainability) into a highly relevant target group in marketing [29-31] can be seen in this context. The following paragraphs show how the broader meaning of sustainability changes the original meaning (von Carlowitz) using as example two relevant German discourses on sustainability: the discussion on strong sustainability driven by nature preservation and the discussion about the use of sustainable standards in the building sector. Both discourses are highly relevant for the forest-based sector with one pertaining to raw material availability and the other to market opportunities in the main and key market of the wood-based industry-the building sector (cf. [32]).

\section{Results and Discussion}

\subsection{The SRU Discourse on Strong Sustainability}

The German Advisory Council on the Environment (Sachverständigenrat für Umweltfragen; SRU), as an important opinion former in Germany, continuously publishes a comprehensive report concerning environmental topics, most recently in 2012 [33]. As early as 2002, intense debate by the SRU council on sustainability clearly favored and recommended the concept of strong sustainability [34]. The analysis of the SRU included a clear refusal of the three-pillar model, which was associated in the report with the concept of weak sustainability. The proposal of the SRU calls for prioritizing ecology over economy or social aspects. Renn et al. [9] refer to this concept as the "one-pillar model". The analysis and recommendation among experts concerning the three-pillar model is written in a defense kind; the SRU remarked that the three-pillar model becomes more important in public discussion as the favored concept of strong sustainability prioritizing ecology.

Ten years later the SRU council [33] appears to have taken a more offensive stance. With reference to newer publications concerning climate change and biodiversity [35-37] and a reference to the entropy laws in thermodynamics, the SRU renewed its support for a strong sustainability policy. The SRU proposed a "model of sustainability prioritizing the embedding of human needs in a framework of a restricted environment" ("Nachhaltigkeitsmodell, das die Einbettung menschlicher Aktivitäten in eine begrenzte Umwelt hervorhebt"). The SRU also visualized this priority in graphics which differ in absolute limits (biodiversity, climate, water, etc.) and relative limits (economics, social and ecology). 
These relative limits can be optimized ("Optimierungsgebot”). However, this optimization is limited by the larger framework of environmental limitations (absolute limit). In this way it is possible to keep the commonly accepted idea of the three dimensions shown in the three-pillar model, while at the same time introducing a broader environmental dimension to promote the model of strong sustainability.

The recommendations by the SRU represent a return in part to the principles associated with the original concept of natural sustainability in forestry. In the picture of the travelling concept this can be seen as a journey back in time to the pre-Brundtland-era. This scenario clearly demonstrates that promoting the principles of sustainable raw material production should privilege an established sustainable forestry industry. Forest products should be given a market advantage over other competing materials, e.g., coal or oil based materials, such as plastics. However, this argument is just as insufficient as the expert's opinion described in the introduction. There are three relevant reasons: (1) The SRU concept [33] focuses on the benefits of the ecosystem model in which the production of wood is only one part of the "provisioning services". While the earlier report emphasized the terms nature capital ("Naturkapital") and raw material production [34], the 2012 SRU report focuses on the new key words climate and biodiversity, not raw material production. This change can be understood as a shift from a more anthropocentric to a more biocentric view; (2) At the same time, the 2012 SRU report only considers the effects of biomass accumulation in the forests as a strategy for climate protection and not the contribution of the forestry-based industry in general (carbon storage in wood products, substitution effects on energy and material use of wood; e.g., [38-40]). This aspect has long been a topic of a public debate between German forestry scientists and the SRU (see [41,42]); (3) The implementation of the recommended principles in a limited framework, such as forestry, seems more plausible than a general implementation in economics and society, particularly the possibility of negative economic growth which is described in the SRU expertise. Changes in forestry and forest management seem more likely as a deeper transformation process with the acceptance of deadweight losses (acceptance of a loss in economic efficiency). In consequence, it is more probable that the idea of strong sustainability will be implemented in forestry with the restriction of wood use (particularly if no wood use is favored as a means of mitigating climate change) rather than in the economy (e.g., the building sector) where the contrary can be observed (see below).

The SRU's argument is undefined and subject to variation, particularly in articles closely linked to nature protection ( $c f$. to the relevant stakeholder [9,43]). Niekisch, a member of the SRU, e.g., visualizes the concept with a pillar-model similar to the three-pillar-model, with the exception that the term culture is added and the ecological dimension (with the terms climate and biodiversity) builds the foundation instead of an equitable dimension, such as the economy [44]. Figure 1 illustrates Niekisch's argument [44] Krug and Jessel propose a new multifunctional forestry with a strong emphasis on nature protection and none-use forests [45]. The proposal of Krug and Jessel exceeds the targets of the National Biodiversity Strategy (Nationale Strategie zur biologischen Vielfalt) [46], which aims to establish $5 \%$ of forest areas in Germany through natural development by 2020. This strategy was evaluated with a renouncement of $4.4 \mathrm{Mm}^{3}$ wood $\left(6.6 \mathrm{Mm}^{3}\right.$ biomass $)$ use per year [47]. It is important to acknowledge that forests are increasingly gaining public attention as building standards and nature protection take on an ever greater value in society (e.g., [48,49]). That means, it would likely be much easier to limit wood production than it would be to implement other measures, e.g., economic, the more so since the majority of the German forests are publically held. 
Figure 1. The interpretation of the strong sustainability concept prioritizing the biodiversity or climate dimension, illustration based on Niekisch [44].

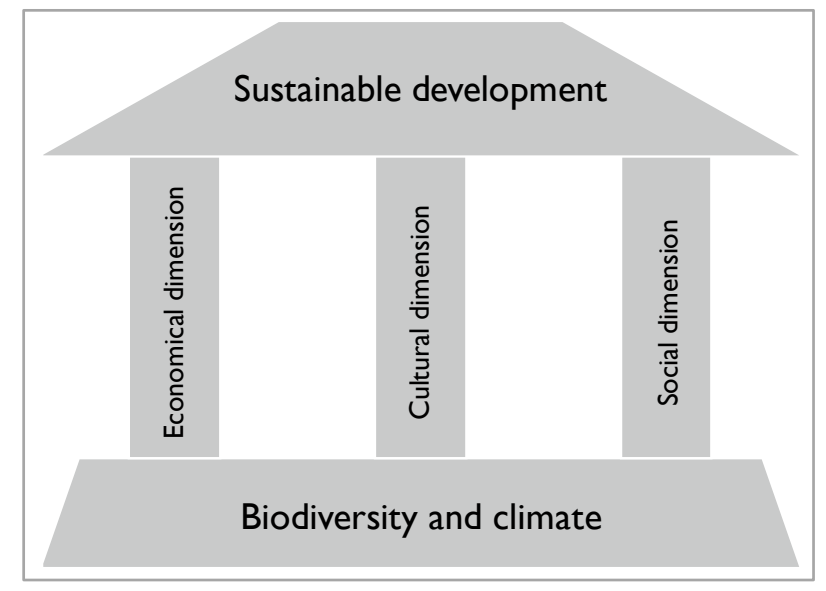

\subsection{Sustainable Standards in the Building Sector}

Since the middle of the 2000s intense discussion has been taking place in Germany about sustainable building practices. This discussion is embedded in the context of international standard specifications (e.g., ISO/TC 59/SC 17) and the importance of sustainability in German economics and public policy. Consequently, the German Sustainable Building Council (Deutsche Gesellschaft für Nachhaltiges Bauen; DGNB) was founded in 2007. Members of the DGNB are architects, construction companies, manufacturers of building products, as well as investors, contractors, scientific organizations, etc. In addition to the non-profit organization DGNB, the Ministry of Transport, Building and Urban Affairs (Bundesministerium für Verkehr, Bau und Stadtentwicklung; BMVBS) was engaged in development of standards for sustainable building. Working together, these two institutions developed and published criteria for sustainable building, e.g., the Guideline for Sustainable Building (Leitfaden für Nachhaltiges Bauen [50]).

Compared to other countries, environmental standardization in the German building sector started late. The UK System BREEAM (Building Research Establishment Environmental Assessment Methodology; cf. [51]) was published in 1990 and the US system LEED (Leadership in Energy and Environmental Design; $c f$. [52] in 1998. Other countries have also developed national certification systems, e.g., HQE in France (cf. [53]) or CASBEE (cf. [54]) in Japan. The German system shows a difference: While the standards LEED and BREEAM refer to environment and energy (green building) the German system applies to sustainability. Content and criteria of the different systems used in the USA are compared in [55]; the highest rated criterion by the BREEAM system is energy, by LEED energy and atmosphere.

The different systems facilitate an assessment on environment, energy or sustainability and classify buildings through certification awards (e.g., LEED: platinum, gold, silver, certified; BREEAM: outstanding, excellent, very good, good, pass; DGNB: gold, silver, bronze). These assessments use point or percent ratings. The DGNB/BMVBS assessment uses a scoring system based on the three dimensions of sustainability: economic quality, socio-cultural quality and ecological quality (each with a share of $22.5 \%$ ). $22.5 \%$ is scored for technical quality and $10 \%$ for process quality (for the criteria and its operationalization see [56]. In this system the relevance of sustainability in the sense of a 
renewable material is marginal—only the criterion "sustainable logging/wood" refers to this approach with a low factor of relevance and a percentage share of overall result of $1.125 \%$ (sic!), $c f$. Figure 2 . Criteria with a possible advantage for wood (GWP, PE or sustainable logging) add to approx. 10\%; the assessment of other criteria in relationship to wood is unclear or possibly disadvantageous (thermal comfort in summer, indoor air quality, sound isolation); these three criteria add to approx. $11 \%$.

Figure 2. Weighting the main criteria in the German DGNB system and minor share of relevance given sustainability in the sense of a renewable material $[50,56]$.

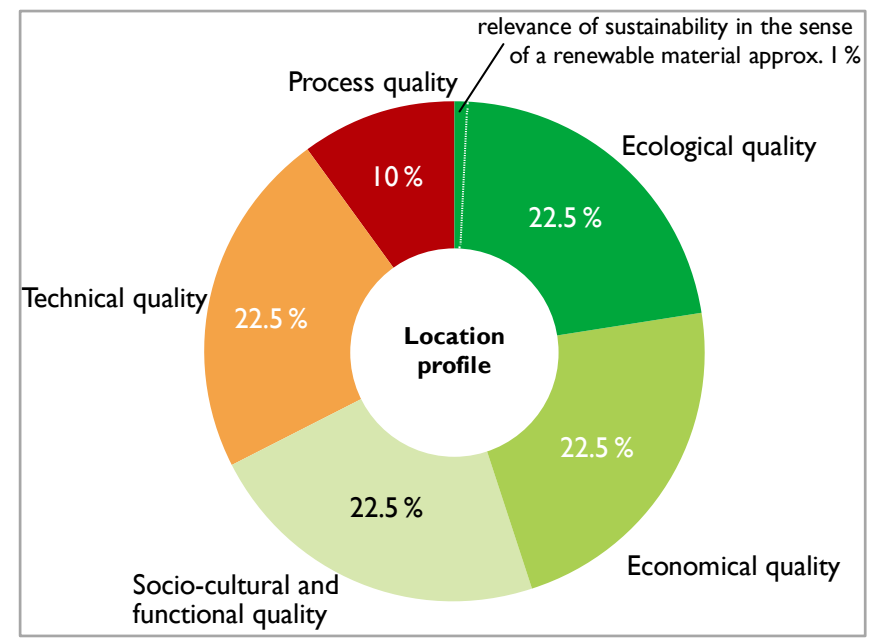

A deeper consideration is needed to evaluate exactly the relationship of the DGNB/BMVBS assessment with wood (for such a consideration see the overview of the green building systems in USA market [55]). However, one statement is possible without deeper analysis: The criteria of the German rating system do not prioritize wood (or other renewable raw materials) as building material. There are two reasons: (1) an advantage like "renewable" is not (really) considered; (2) Most of the criteria are generally irrelevant in the view of different materials (e.g., art in architecture, bicycle comfort, barrier-free building, etc.). Thus, a possible advantage for one material over another is not easily to determine.

The German Certificate of Sustainable Building (Deutsches Gütesiegel für Nachhaltiges Bauen) seems to be successful in the German building sector, particularity in the traditional (concrete) construction sector (see [57]). This confirms the expectation by the sector's experts that sustainability would increase in importance in the building sector (see above). However, the expectation that wood would gain in relevance in the building sector is not substantiated. If up to now building with wood could be marketed as especially sustainable, this market opportunity is lost in the new rating system of sustainability building. In fact, the implementation of sustainable criteria in the building sector could even be considered disadvantageous for the forest-based sector. The reasons for this development and the non-considering of wood can be attributed to the wood industry's lack of participation in development of the criteria; the process mainly took place without the participation of the wood-based sector, so it is comprehensible that the concrete construction industry did not consider the advantages of building with wood.

Interestingly, the rating system of sustainable building is formed in a way that the SRU (see above) criticizes - economic interests dominate sustainability and undermine the environmental aspects. 


\section{Conclusions}

A closer look at the two current lines of discourse regarding the term sustainability in Germany shows that each has developed and established a diametrically opposed meaning. While the discourse on strong sustainability narrows the term of sustainability and prioritizes the ecological and environmental dimension (biodiversity and climate protection); the discourse on sustainable building broadens the term of sustainability while scarcely considering the aspect of renewable resources. The development and establishment of opposed meanings is absolutely consistent with the idea of travelling concepts. However, as a result, the two meanings could pose a challenge to the German forestry sector by reducing the raw material base or minimizing market opportunities. The paradox: As the term sustainability, which originated in the forestry sector, becomes mainstream, it could in turn reduce the sector's chances for growth.

Approaching sustainability as a travelling concept also provides a more positive outlook for the possible future. The term sustainability's journey may potentially take another path if its meaning changes over time. One potential for the forestry and the forest-based sector could be the advantages of wood as a renewable material in the context of energy and climate policy. Research in the forest-based sector shows the advantages of forests and wood with regard to carbon management and climate protection [38-40,58-68] and energy policy as a renewable energy carrier with low $\mathrm{CO}_{2}$-emissions [69-71]. The topics of wood as a renewable energy carrier and its role in climate protection are also included in the concept of strong sustainability ( $c f$. Figure 1) but currently conflict with the dominating topic of nature protection. Furthermore, climate protection and energy sources are main issues in policy decisions, e.g., [72,73]. It is possible that the topics of energy and climate protection will influence the further development of the term sustainability's meaning and (re-) establish the concept of a sustainable forest-based sector (or the concept of sustainability in the forest-based sector) in policy and society.

\section{Conflicts of Interest}

The author declares no conflict of interest.

\section{References}

1. Knauf, M.; Frühwald, A. Die Zukunft der deutschen Holzwirtschaft. "Delphistudie Holz 2020 revisited"-Nachhaltigkeit—Politischer Einfluss der Holzwirtschaft (Teil II). Holz-Zentralblatt 2011, 137, 132.

2. Knauf, M. Trends und Perspektiven in der Forst-und Holzwirtschaft. In Tagungsband Deutsche Holzschutztagung 2012; University of Göttingen: Göttingen, Germany, 2012.

3. Bal, M. Travelling Concepts in the Humanities; University of Toronto Press: Toronto, ON, Canada, 2002.

4. Bal, M. Working with Concepts. Eur. J. Engl. Stud. 2009, 13, 13-23.

5. Prengel, A. Inklusion in der Früpädagogik. Bildungstheoretische, Empirische und Pädagogische Grundlagen; Fachkrafte, W.F.G., Ed.; Deutsches Jugendinstitut e.V.: Munich, Germany, 2014.

6. Walgenbach, K. Diversity Education—Eine kritische Zwischenbilanz. Neue Prax. 2012, 3, 242-254. 
7. Olson, G. Gender as a Travelling Concept: A Feminist Perspective; De Gruyter: Berlin, Germany, 2012; pp. 205-224.

8. Knapp, G.-A. Race, Class, Gender Reclaiming Baggage in Fast Travelling Theories. Eur. J. Women's Stud. 2005, 12, 249-265.

9. Renn, O.; Deuschle, J.; Jäger, A.; Weimer-Jehle, W. Leitbild Nachhaltigkeit-Eine Normativ-Funktionale Konzeption und Ihre Umsetzung; VS Verlag für Sozialwissenschaften: Wiesbaden, Germany, 2007.

10. Von Carlowitz, H.C. Sylvicultura Oeconomica oder Haußwirthliche Nachricht und Naturmäßige Anweisung zur Wilden Baum-Zucht; Hamberger, J., Ed.; Oekom-Verlag: Munich, Germany, 1713.

11. Grober, U. Die Entdeckung der Nachhaltigkeit; Kunstmann: Munich, Germany, 2010.

12. Hartig, G.L. Anweisung zur Taxation der Forste, oder zur Bestimmung des Holzertrags der Wälder: Ein Beytrag zur Höheren Forstwissenschaft; Heyer: Giessen, Germany, 1795.

13. Cotta, H. Anweisung zum Waldbau; Arnoldische Buchhandlung: Dresden, Germany, 1817.

14. Gayer, K. Der Waldbau; P. Parey: Berlin, Germany, 1882.

15. Möller, A. Der Dauerwaldgedanke. Sein Sinn und Seine Bedeutung; Degreif: Michendorf, Germany, 1923.

16. United Nations. Our Common Future; Report of the World Commission on Environment and Development; United Nations: New York, NY, USA, 1987.

17. United Nations. Report of the United Nations Conference on Environment and Development. In Proceedings of the Rio Declaration on Environment and Development, Rio de Janeiro, Brazil, 3-14 June 1992.

18. Coenen, F. Local Agenda 21: "Meaningful and Effective" Participation? In Public Participation in Environmental Assessment and Decision Making; Coenen, F., Ed.; Springer Netherlands: Dordrecht, Holland, 2009; pp. 165-182.

19. Kajikawa, Y.; Ohno, J.; Takeda, Y.; Matsushima, K.; Komiyama, H. Creating an academic landscape of sustainability science: An analysis of the citation network. Sustain. Sci. 2007, 2, 221-231.

20. Kajikawa, Y. Research core and framework of sustainability science. Sustain. Sci. 2008, 3, 239-251.

21. Christen, M.; Schmidt, S. A Formal Framework for Conceptions of Sustainability-A Theoretical Contribution to the Discourse in Sustainable Development. Sustain. Dev. 2012, 20, 400-410.

22. Hugé, J.; Waas, T.; Dahdouh-Guebas, F.; Koedam, N.; Block, T. A discourse-analytical perspective on sustainability assessment: Interpreting sustainable development in practice. Sustain. Sci. 2013, 8, 187-198.

23. ITTO. Revised ITTO Criteria and Indicators for Sustainable Management of Tropical Forests Including Reporting Format; ITTO: Yokohama, Japan, 2005.

24. ITTO. Status of Tropical Forest Management 2011; ITTO: Yokohama, Japan, 2011.

25. Montréal Process Criteria and Indicators for the Conservation and Sustainable Management of Temperate and Boreal Forests, 4th ed.; Montréal Process: Tokyo, Japan, 2009.

26. Improved Pan-European Indicators for Sustainable Forest Management; MCPFE: Vienna, Austria, 2002. 
27. State of Europe's Forests 2011: Status and Trends in Sustainable Forest Management in Europe; Forest Europe: Oslo, Norway, 2011.

28. Bojanovski, A. Verwirrende Werbefloskel. APuZ 2014, 64, 7-8.

29. Ray, P.H.; Anderson, S.R. The Cultural Creatives: How 50 Million People Are Changing the World; Broadway Books: New York, NY, USA, 2001.

30. Wenzel, E.; Kirig, A.; Rauch, C. Greenomics: Wie der Grüne Lifestyle Märkte und Konsumenten Verändert; Redline Verlag: Munich, Germany, 2008.

31. Kirig, A.; Wenzel, E. LOHAS: Bewusst Grün-Alles über Die Neuen Lebenswelten; Redline Verlag: Munich, Germany, 2009.

32. Mantau, U.; Bilitewski, B. Stoffstrom-Modell-Holz Bestimmung des Aufkommens, der Verwendung und des Verbleibs von Holzprodukten. Forschungsbericht für den Verband Deutscher Papierfabriken e. V. (VDP); Infro/intectus: Celle, Germany 2010.

33. SRU. Umweltgutachten 2012-Verantwortung in Einer Begrenzten Welt; Erich Schmidt Verlag: Berlin, Germany, 2012.

34. Umweltgutachten 2002-Für eine neue Vorreiterrolle. Gutachten des Rates von Sachverständigen für Umweltfragen; Deutscher Bundestag: Berlin, Germany, 2002; p. 549.

35. Climate Change 2007: Synthesis Report; IPCC: Geneva, Switzerland, 2007.

36. The European Environment-State and Outlook 2010: Assessment of Global Megatrends; EEA: Copenhagen, Denmark, 2010.

37. Millennium Ecosystem Assessment. Ecosystems and Human Well-being: Synthesis; Island Press: Washington, DC, USA, 2005.

38. Taverna, R.; Hofer, P.; Werner, F.; Kaufmann, E.; Thürig, E. The CO Effects of the Swiss Forestry and Timber Industry. Scenarios of Future Potential for Climate-Change Mitigation; FOEN: Bern, Switzerland, 2007.

39. Lundmark, T.; Bergh, J.; Hofer, P.; Lundström, A.; Nordin, A.; Poudel, B.; Sathre, R.; Taverna, R.; Werner, F. Potential Roles of Swedish Forestry in the Context of Climate Change Mitigation. Forests 2014, 5, 557-578.

40. Frühwald, A.; Knauf, M. Carbon Aspects Promote Building with Wood. In Proceedings of the World Conference on Timber Engineering WCTE, Quebec, Canada, 10-14 August 2014.

41. Erler, J.; Becker, G.; Spellmann, H.; Dieter, M.; Ammer, C.; Bauhus, J.; Bitter, A.; Bolte, A.; Knoke, T.; Köhl, M.; et.al. Forstwissenschaftler bemängeln Umweltgutachten 2012 des SRU: Einseitig, widersprüchlich und teilweise falsch. AFZ Der Wald 2012, 67, 22-26.

42. Umweltgerechte Waldnutzung. Gut begründet und Erforderlich-Anmerkungen zur Kritik einer Gruppe von Forstwissenschaftlern am Kapitel 6, Umweltgerechte Waldnutzung, des Umweltgutachtens 2012, Verantwortung in einer begrenzten Welt; SRU: Berlin, Germany, 2012.

43. Tremmel, J. Nachhaltigkeit als Politische und Analytische Kategorie. Der Deutsche Diskurs um Nachhaltige Entwicklung im Spiegel der Interessen der Akteure; Oekom-Verlag: Munich, Germany, 2003.

44. Niekisch, M. Reichtum in Gefahr. Biologische Diversität in den Tropenwäldern. In Wald. Politische Spielräume Zwischen Baum und Borke; Oekom Verlag: Munich, Germany, 2013; pp. 73-80. 
45. Krug, A.; Jessel, B. Durch die Naturschutzbrille betrachtet. Nachhaltigkeit in der Forstwirtschaft. In Wald. Politische Spielräume Zwischen Baum und Borke; Oekom-Verlag: Munich, Germany, 2013.

46. Nationale Strategie zur Biologischen Vielfalt; BMU: Berlin, Germany, 2007.

47. Dieter, M. Volkswirtschaftliche Betrachtung von holzbasierter Wertschöpfung in Deutschland. Agric. For. Res. Sonderh. 2009, 327, 37-46.

48. Naturbewusstsein 2011-Bevölkerungsumfrage zu Natur und Biologischer Vielfalt; BMU UBA: Berlin, Germany, 2012.

49. Umweltbewusstsein in Deutschland 2012-Ergebnisse einer repräsentativen Bevölkerungsumfrage; BMU/UBA: Berlin, Germany, 2013.

50. Leitfaden Nachhaltiges Bauen; BMVBS: Berlin, Germany, 2013.

51. BREEAM. Available online: http://www.breeam.org (accessed on 21 October 2014).

52. USGBC. Available online: http://www.usgbc.org (accessed on 21 October 2014).

53. ASSOHQE. Available online: http://www.assohqe.org (accessed on 21 October 2014).

54. JaGBCJSBC. Available online: http://www.ibec.or.jp/CASBEE/english/index.htm (accessed on 21 October 2014).

55. Overview of Green Building Rating Systems and Their Relationship(s) with Wood; Light House Sustainable Building Centre: Vancouver, BC, Canada, 2013.

56. Sustainability Criteria; BMVBS: Berlin, Germany, 2014.

57. Das Deutsche Gütesiegel Nachhaltiges Bauen. Aufbau-Anwendung-Kriterien, Stand 03/2009; DGNB: Stuttgart, Germany, 2009.

58. Burschel, P.; Kürsten, E.; Larson, B.C. Die Rolle von Wald und Forstwirtschaft im Kohlenstoffhaushalt: Eine Betrachtung für die Bundesrepublik Deutschland; Schriftenreihe der Forstwissenschaftlichen Fakultät der Universität München und Bayerischen Forstlichen Versuchs- und Forschungsanstalt: München, Germany, 1993; Volume 126.

59. Frühwald, A.; Wegener, G. Energiekreislauf Holz-Ein Vorbild für die Zukunft. Holz-Zentralblatt 1993, 119, 1949-1951.

60. Perez-Garcia, J.; Lippke, B.; Comnick, J. An assessment of carbon pools, storage, and wood products market substitution using life-cycle analysis results. Wood Fiber Sci. 2005, 37, 140-148.

61. Skog, K.E. Sequestration of carbon in harvested wood products for the United States. For. Prod. J. 2008, 56, 56-72.

62. Frühwald, A.; Solberg, B. LCA-A Challenge for Forestry and Forest Products Industry; European Forest Institute: Joensuu, Finland, 1995.

63. Puettmann, M.E.; Wilson, J.B. Life-cycle analysis of wood products: Cradle-to-gate LCI of residential wood building materials. Wood Fiber Sci. 2005, 37, 18-29.

64. Wilson, J.B.; Sakimoto, E.T. Gate-to-gate life-cycle inventory of softwood plywood production. Wood Fiber Sci. 2005, 37, 58-73.

65. Winistorfer, P.; Chen, Z.; Lippke, B.; Stevens, N. Energy Consumption and Greenhouse Gas Emissions Related to the use, Maintenance, and Disposal of a Residential Structure. Wood Fiber Sci. 2005, 37, 128-139. 
66. Karjalainen, T.; Zimmer, B.; Berg, S.; Welling, J.; Schwaiger, H.; Finér, L.; Cortijo, P. Energy, Carbon and Other Material Flows in the Life Cycle Assessment of Forestry and Forest Products; Discussion Paper 10; European Forest Institute: Joensuu, Finland, 2001.

67. Lippke, B.; Wilson, J.; Perez-Garcia, J.; Bowyer, J.; Meil, J. CORRIM: Life-cycle environmental performance of renewable building materials. For. Pro. J. 2004, 54, 8-19.

68. Sathre, R.; O'Connor, J. A Synthesis of Research on Wood Products and Greenhouse Gas Impacts, 2nd ed.; FPInnovations: Pointe-Claire, QC, Canada, 2010.

69. Reijnders, L. Conditions for the sustainability of biomass based fuel use. Energy Policy 2006, $34,863-876$.

70. Gustavsson, L.; Holmberg, J.; Dornburg, V.; Sathre, R.; Eggers, T.; Mahapatra, K.; Marland, G. Using biomass for climate change mitigation and oil use reduction. Energy Policy 2007, $35,5671-5691$.

71. Sathre, R.; Gustavsson, L. A State-of-the-Art Review of Energy and Climate Effects of Wood Product Substitution; School of Technology and Design Reports 57; University Växjö: Växjö, Sweden, 2009.

72. Bentsen, N.S.; Felby, C. Biomass for energy in the European Union-A review of bioenergy resource assessments. Biotechnol. Biofuels 2012, 5, 25.

73. Directive 2009/28/EC of the European Parliament and of the Council of 23 April 2009 on the Promotion of the Use of Energy from Renewable Sources and Amending and Subsequently Repealing Directives 2001/77/EC and 2003/30/EC; European Parliament and the Council: Brussels, Belgium, 2009.

(C) 2014 by the author; licensee MDPI, Basel, Switzerland. This article is an open access article distributed under the terms and conditions of the Creative Commons Attribution license (http://creativecommons.org/licenses/by/4.0/). 